\title{
Topikalizacja \\ w tekstach Cypriana Norwida. Rekonesans
}

\author{
Anna Kozłowska
}

ORCID: 0000-0001-7465-9316

|

Jak wiadomo, w każdym empirycznym, zrealizowanym i zaktualizowanym zdaniu (czyli w wypowiedzeniu) poza strukturą składniową obecna jest tak zwana struktura tematyczno-rematyczna (STR, funkcjonalne/aktualne rozczłonkowanie zdania), która wyraża uniwersalną strukturę wiedzy: ktoś wie o tym, o czym mowa (wskazanym przez wyrażenie tematyczne), że $p$ (o czym mowa w części rematycznej), a nie nie- $p^{1}$. Tego typu rozczłonkowanie sygnalizowane jest w polszczyźnie przede wszystkim przez akcent zdaniowy (kontrastywny), intonację oraz pauzy (zwłaszcza tzw. cezurę tematyczną).

W wypowiedzeniach zachowujących neutralną STR w oczywisty sposób wyróżniona jest przede wszystkim część rematyczna. W wypowiedzeniach o STR nacechowanej (sekundarnej) możliwe jest również uwydatnienie części tematycznej², które na potrzeby niniejszego tekstu będę nazywała topikalizacją ${ }^{3}$. Operacji tej służą w polszczyźnie przede wszystkim środki składniowe, takie jak diateza i zmiana szyku przy diatezie nienacechowanej, leksykalne oraz prozodyczne ${ }^{4}$.

$\mathrm{Na}$ to, że „problem topikalizacji jest [...] jednym z zasadniczych problemów Norwidowego sposobu mówienia", jako pierwsza zwróciła uwagę Jolanta Chojak, omawiając funkcje Norwidowskich pytaj-

${ }^{1}$ Zob. Andrzej Bogusławski, Problems of the Thematic-Rhematic Structure of Sentences (Warszawa: Państwowe Wydawnictwo Naukowe, 1977), 229 i n.; tenże, A Study in the Linguistics - Philosophy Interface (Warszawa: BEL Studio, 2007).

${ }^{2}$ W związku z pojęciami tematu oraz rematu normalnego i uwydatnionego zob. Romuald Huszcza, „Tematycznorematyczna struktura zdania w języku polskim”, Polonica VI (1980): 57-81; tenże, „Tematyczno-rematyczna struktura zdania w językach różnych typów. (Normalny podział tematyczno-rematyczny)”, w: Tekst w kontekście, red. T. Dobrzyńska (Wrocław: Ossolineum, 1990), 58-59.

${ }^{3}$ W części literatury przedmiotu topikalizację rozumie się również węziej, jako nadawanie statusu tematu części zdania innej niż podmiot. Zuzanna Topolińska używa natomiast tego terminu jako synonimicznego wobec określeń: struktura tematyczno rematyczna oraz aktualne rozczłonkowanie zdania (zob. Z. Topolińska, „Informacja zgramatykalizowana [kryteria selekcji]", Biuletyn PTJ LXVIII [2012]: 72).

${ }^{4}$ Zob. Jolanta Chojak, Zofia Zaron, „Wyznaczniki tematu wypowiedzi”, Polonica XXIV-XXV (2005), 24; S.

Karolak, „Aktualne rozczłonkowanie zdania”, w: Encyklopedia językoznawstwa ogólnego, red. K. Polański (Wrocław: Ossolineum, 1995), 33. 
ników wewnątrzzdaniowych ${ }^{5}$. Badaczka nie rozwinęła jednak tej tezy ani jej szerzej nie udokumentowała. Całościowej analizy zjawiska topikalizacji w pismach autora Vade-mecum nie przyniesie również niniejszy artykuł, który jest raczej próbą wstępnego rozpoznania specyfiki i roli tego zabiegu niż jego kompletną monografią. Stawiam sobie tu tylko dwa cele: 1. prezentację właściwych Norwidowi, a zarazem częściowo nieoczywistych dla współczesnego odbiorcy wykładników tej operacji; 2. próbę odpowiedzi na pytanie o jej miejsce w Norwidowej praktyce konstruowania wypowiedzeń.

II

W pismach Norwida, podobnie jak w polszczyźnie ogólnej, za interesujący mnie tu efekt uwydatnienia tematu odpowiadają przede wszystkim mechanizmy syntaktyczne. W zdaniach o nienacechowanej diatezie podstawowym składniowym wykładnikiem topikalizacji jest inwersja, którą autor Vade-mecum stosował chętnie i często. Na przykład we fragmencie wiersze Cenzor-krytyk temat pierwszego zdania został zgodnie z konwencją wysunięty na początek:

Autorów, sądzą ich dzieła,

Nie, autorzy autorów! [VM 54] ${ }^{6}$

Schemat ten nie powtarza się jednak w wersie drugim - tu na początku znajduje się komponent nowy („autorzy”), którego nie oddziela od wykładnika tematu („autorów”) żadna pauza. Pauzę (sygnalizowaną w edycji myślnikiem, a w autografie - przecinkiem) wyznaczył autor tym razem w innym miejscu - przed wyrażeniem rematycznym, czyli tak, aby intonacyjnie uwypuklić novum. W efekcie tematy obu zdań składowych tworzą klamrę kompozycyjną tego dystychu, pojawiając się na jego początku i w zakończeniu.

Kluczową rolę w kształtowaniu STR odgrywa diateza. Norwid nie nadużywał wprawdzie strony biernej, ale potrafił sprawnie posługiwać się nią w celu sygnalizowania hierarchii argumentów, tak na przykład w ostatnim dwuwierszu poniższego fragmentu:

${ }^{5}$ Zob. Jolanta Chojak, „Echa nie zadanych pytań czy wyróżnione tematy (o pewnych użyciach Norwidowskiego pytajnika), w: Studia nad jezzkiem Cypriana Norwida, red. J. Chojak, J. Puzynina (Warszawa: Wydawnictwo Uniwersytetu Warszawskiego, 1990), 33.

${ }^{6}$ Większość tekstów Norwida przytaczam według podstawowego wydania: Cyprian Norwid, Pisma wszystkie. Zebrał, tekst ustalił, wstępem i uwagami krytycznymi opatrzył J.W. Gomulicki, t. 1-11 (Warszawa: Państwowy Instytut Wydawniczy, 1971-1976) (dalej jako PWsz). Tam, gdzie to było możliwe, posługiwałam się jednak nową edycją Dzieł wszystkich Norwida przygotowywaną na KUL przez zespół pod redakcją Stefana Sawickiego: t. 3. Poematy cz. I, oprac. S. Sawicki, A. Cedro (Lublin: Towarzystwo Naukowe KUL, 2009); t. 4. Poematy cz. II, oprac. S. Sawicki, P. Chlebowski, Lublin 2011; t. 5. Dramaty cz. I, oprac. J. Maślanka, Lublin 2015; t. 6. Dramaty cz. II, oprac. J. Maślanka (Lublin: Towarzystwo Naukowe KUL, 2013); t. 7. Proza cz. I, oprac. R. Skręt (Lublin: Towarzystwo Naukowe KUL, 2007); t. 10. Listy cz. I, 1839-1854, oprac. J. Rudnicka (Lublin: Towarzystwo Naukowe KUL, 2008); t. 11. Listy cz. II, oprac. J. Rudnicka (Lublin: Towarzystwo Naukowe KUL, 2016); t. 12. Listy cz. III, oprac. J. Rudnicka, uzup. E. Lijewska (Lublin: Towarzystwo Naukowe KUL, 2019) (dalej jako DWsz) oraz wersjami przygotowanymi w trakcie prac nad wydaniem krytycznym: Cyprian Norwid, Vade-mecum, oprac. J. Fert (Lublin: Towarzystwo Naukowe KUL, 2004). W cytatach i odnośnikach pierwsza liczba po skrócie tytułu oznacza tom, druga - numer strony. Decyzja o korzystaniu z różnych wydań pociąga za sobą rozbieżności między pojawiającymi się w artykule konwencjami graficznymi - szczególnie dotyczy to Norwidowskich wyróżnień, które w rękopisach realizowane są jako podkreślenia, w PWsz - oddawane w postaci rozstrzelonego druku, natomiast w lubelskim wydaniu - zaznaczane kursywą. Do niektórych analizowanych przykładów wprowadziłam istotne z punktu widzenia analizy języka poprawki, przywracając tekstom oryginalną autorską grafię na podstawie rękopisów udostępnianych przez bibliotekę cyfrową Polona (www.polona.pl; zob. też Cyprian Norwid, „Vade-mecum”. Transliteracja autografu, oprac. i wstępem opatrzył M. Grabowski [Łódź: Wydawnictwo Uniwersytetu Łódzkiego, 2018]) oraz Bibliotekę Cyfrową Muzeum Narodowego w Krakowie (http://cyfrowe.mnk.pl). 


\author{
Dziś właśnie przeto nic nie jest dostałe \\ W życiu i w sztuce, i w dziejów osnowie, \\ Że, co się robi, w myśli pierw jest całe, \\ Czyli ułomne, bo dopiero w głowie. \\ I nikt nie waży się, czy on dokona? \\ (Przykładem męża, co ma stawić wieżę, \\ Lecz zali wieża może być stawiona?...) - [PWsz 1, 232]
}

Pasywizacja, która skutkuje nadaniem statusu tematu obiektowi czynności, wprowadza tu subtelne skontrastowanie dwóch perspektyw: ambicji przyszłego budowniczego (wyrażonych w stronie czynnej) i realnych wymagań związanych z planowanym dziełem (sygnalizowanych przez zdanie o nacechowanej diatezie, w stronie biernej).

Na szczególną uwagę badacza STR zasługują te sytuacje, w których autorowi Vade-mecum zdarzały się anakoluty. Być może właśnie potrzebą eksponowania tematu (czy szerzej - prymatem struktury tematyczno-rematycznej wobec składniowej) należałoby tłumaczyć na przykład niektóre błędne Norwidowskie konstrukcje z imiesłowem przysłówkowym, zwłaszcza te, w których wyrażenie partycypialne zostało użyte w stronie biernej:

Owszem - lecz śpiesz się, oto bowiem, kwiat

Nie będąc na czas zrobiony,

Odmieniać muszę włosów tok i szat,

Wieczór mój! - prawie s t r a c o n y ! [Malarz z konieczności, PWsz 1, 317]

lub w których występuje niewłaściwa forma imiesłowu - na przykład imiesłów czynny zamiast biernego:

Nić, objąwszy iskrą, zrazu płonie,

Zalewa wosk, który górą wstawa [VM 248] ${ }^{7}$

Problematyka oznajmień imiesłowowych w tekstach Norwida doczekała się już wprawdzie kilku omówień, a skłonność poety do wykolejeń w tym zakresie bywała rozmaicie wyjaśniana i uzasadniana ${ }^{8}$, ale w żadnym opracowaniu nie odwoływano się do obserwacji z płaszczyzny STR. Tymczasem przynajmniej w tych użyciach, w których na Norwidowe kłopoty z imiesłowami nakłada się problem diatezy, wyjaśnienia, a częściowo i usprawiedliwienia dla uchybień poety można chyba szukać w jego dążeniu do zaakcentowania tematu; w przywołanych przykładach dzięki naruszeniu zasad poprawności gramatycznej wyrażenie wskazujące na temat pełni przecież funkcję podmiotu co najmniej jednego wypowiedzenia składowego (w drugim cytacie - także wypowiedzenia nadrzędnego). Trudno chyba przypuszczać, żeby Norwid świadomie i celowo zmierzał do takiego

${ }^{7}$ Przywołany fragment pochodzi w wariantowej redakcji wiersza Ciemność. Wydaje się, że właściwsza byłaby tu forma imiesłowu biernego „objęta”.

${ }^{8}$ Zob. m.in.: Jadwiga Puzynina, „Z problemów składni w tekstach poetyckich Norwida (na materiale Vademecum)”, w: taż, Słowo Norwida (Wrocław: Ossolineum, 1990), 100-101; Agnieszka Słoboda, „Imiesłowy u Norwida”, Poznańskie Studia Polonistyczne. Seria Językoznawcza 8 (2001): 145; Anna Kozłowska, „Kilka uwag o archaicznych elementach składniowych w tekstach Cypriana Norwida”, Studia Norwidiana 29 (2011): 101-104; Anna Ciołek, „Imiesłowowe równoważniki zdań w listach C.K. Norwida”, Poradnik Językowy 7 (2015): 23-31. 
właśnie efektu; raczej sam był tak mocno pochłonięty myślą o wybranym temacie, że kwestie gramatycznej organizacji całości wypowiedzenia i wymogi poprawności musiały zejść na dalszy plan.

Być może dążenie do zaakcentowana tematu wspierało również obecność w tekstach Norwida konstrukcji nieagentywnych z czasownikami z się pełniącymi funkcję orzeczenia, połączonymi związkiem zgody z mianownikiem:

napotykają się widoki cokolwiek zbliżone do tych, które w Rzymie napotykasz [DWsz 7, 46]

Prawda, się razem dochodzi i czeka! [VM 57]

W czasach Norwida takie wyrażenia, w których miejsce podmiotu zajmuje obiekt czynności, stanowiły już relikt stanu staro- i średniopolskiego. W wieku XVII i XVIII przechodziły one stopniowo do kategorii bezpodmiotowych, czego wykładnikiem stała się bezosobowa forma czasownika połączona z biernikiem, zastępująca wcześniej używaną osobową formę zwrotną w związku $\mathrm{z}$ mianownikiem (ziemia się uprawia -> ziemię się uprawia) ${ }^{9}$. Ponieważ zmiany te reorganizowały układ argumentów, niewykluczone, że upodobanie Norwida do używania form archaicznych wynikało między innymi z chęci zachowania takiej diatezy, w której obiekty czynności (w powyższych przykładach są to „widoki” i „prawda”) pozostają tematami odpowiednich wypowiedzeń.

Do ciekawych i typowo Norwidowskich zabiegów tekstowych wzmacniających temat należy obudowywanie go nawiasowymi dopowiedzeniami, które stanowią „rodzaj dygresji, ujawniającej istnienie nadawcy tekstu głównego (komentarz do tekstu głównego)" i tym samym są „metatekstem nadbudowanym nad tekst «prowadzący»"10.

Ona zaś (mówię: Poezja), swe ramię

Blade ku oknu niosąc, znak mi dała,

Bym światło przyćmił, bo uśmiechy kłamie [...]

Umarła ona (Poezja), ta wielka

Niepojednanych dwóch sfer pośrednica,

Ocean chuci i rosy kropelka,

Ta monarchini i ta wyrobnica - [PWsz 2, 200]

Zygmunt* (nieboszczyk) raz mówił mi żartem,

[... ] Twierdząc, że - mimo opóźnionej pieczy -

Kto dziś się jeszcze w dzieje [w autografie brak części utworu] [VM 90]

Zadaniem tego rodzaju parentez jest nie tyle charakteryzowanie obiektu, ile raczej zapewnienie jego precyzyjnej identyfikacji - wskazywanie na aktualny temat wypowiedzi, wyłoniony ze zbioru zapowiadanych wcześniej tematów („onych” bądź „Zygmuntów”), którego zakres może się wydawać jeszcze zbyt szeroki.

${ }_{9}$ Zob. Krystyna Pisarkowa, Historia składni języka polskiego (Wrocław:Ossolineum, 1984), 42-43.

${ }^{10}$ Maciej Grochowski, „Składnia wyrażeń polipredykatywnych”, w: Gramatyka wspótczesnego języka polskiego. Składnia, red. Z. Topolińska (Warszawa: Wydawnictwo PWN, 1984), 249; zob. też tenże, „Metatekstowa interpretacja parentezy”, w: Tekst i zdanie. Zbiór studiów, red. T. Dobrzyńska, E. Janus (Wrocław: Ossolineum, 1983), 247-258. 
|||

W tekstach Norwida można znaleźć także (niezbyt liczne) użycia jednostek, które pełniły funkcję wyrażeń topikalizujących zarówno w XIX-wiecznej polszczyźnie, jak i dziś. Oto kilka przykładów:

à propos:

À propos książąt: czy Pani pamięta wnijście do Salonu naszej pamiętnej księżnej, ale nie od Gedymina jak Golitzinowie pochodzącej, lecz moskiewskiej księżnej, która wyciągnąwszy do mnie rękę rzekła te piękne słowa: „Gałganie! Łajdaku! czemu ty się zrobiłeś emigrantem?” [PWsz 10, 162];

co do:

Co do wyrazu „brzydki”, ten wybrzmiewa: bez-życia, bez-użytku będący; określnik zaś „szkaradny” znaczy: za-karę-dany, czyli potworny, czyli potwór [PWsz VI, 351];

co się tyczy:

Co się tyczy nareszcie podziału historii polskiej na wzrastającą, kwitnącą i upadającą - ten jest o niesłychanie wiele niżej od wszelkiej krytyki [PWsz 7, 66];

jeśli idzie o:

Jeśli tedy idzie o zbawienie Ludzkości nie przez naród (jak to dla jasności znów powtórzę), wedle mnie praca jest niewczesna, a wedle tego, co wczorajsze okazały wypadki, zmarnuje się wiele - nic nie zbawi [PWsz 7, 33];

$w$ kwestii:

w kwestii sakramentu małżeństwa, jedynie za poparciem i wolą Aleksandra Cesarza wszechstronne uprawnienie ROZWODÓW nie nastąpiło [PWsz 8, 259];

w odniesieniu do:

w odniesieniu do powstania 1863 r. mówiąc - niepodobna jest o całej nie mówić Europie [Pwsz $7,96]$.

Poza formułami konwencjonalnymi, powszechnie używanymi w funkcji uwypuklania tematu wypowiedzenia, w tekstach autora Vade-mecum pojawiają się również mniej oczywiste wyrażenia topikalizujące, które mogą przysparzać nieco kłopotów w interpretacji. Jedną z takich jednostek jest przyrzeczownikowe jako. Rozważmy na przykład dwa dłuższe fragmenty listów Norwida do Augusta Cieszkowskiego, pochodzących z jesieni 1850 roku $^{11}$ :

${ }^{11}$ Według edycji DWsz oba listy powstały „przed 13 listopada 1850”. 
FAKTA.

Jako zdrowie i siła - głuchota.

Jako członek Ojczyzny - wszystkie odrzucone rękopisma.

Jako wspomnienia - sąd, że nie jestem dość idealnym przyjacielem.

Jako Kościót - czynny - wojujący - to, co z tym sposobem eskamotowania wiary Chrystusowej stanie się. Jako familia - bracia na tułactwie, z których starszy opuszczony przez krewnego i zdradzony w interesach swoich najhaniebniej.

Jako małżeństwo - to, żem był kochany i zaręczony, ale jak Juliusz mówi: „pfu! odebrałem list, że za mąż idzie" - a potem, jak ten jej majątek stracił i opuścił ją - pisze mi bilecik z przypomnieniem miłości swej. Jako społeczeństwo - to, że społeczeństwo polskie jest najlichsze, tak jak naród polski jest najpierwszy - i że tym sposobem sama znakomitość szwankuje, bo jej zawsze do pokrycia lichości używamy i to, co jest wzniosłego, na szlafrok lichego się przerabia - i stąd nie ma nic. -

Jako znajomości i stosunki - to, że za niedługi przeciąg czasu zrażę je wszystkie, stracę wszystkie - bo, $\mathrm{w}$ nagłych tylko i ostatecznych potrzebach zawzywając pomocy ich, nie mogę naturalnie normalnym odbywać to sposobem - krojem konwencjonalnie słusznym. Tak, jak np. człowiek przejechany na ulicy, kiedy go do znajomych progów pobliskich wnoszą, nie może nie być zbłoconym i skrwawionym - i nie może poczerwienionych nie mieć kołnierzyków u krawaty [DWsz 10, 275]

Przyszedłem organicznie (jako zdrowie i siła) do stanu, w którym jaw jest odbieraniem wrażeń z zewnątrz odpychających najstanowczej. Noc - zawróceniem wzroku wewnątrz.

Jako pozycja - wiesz co?

Jako wspomnienie - od niejakiego czasu coraz więcej płaskie i nikczemne, boć wiesz, czym usprawiedliwiają się raniący - szaleństwem zranionego.

Jako członek Ojczyzny - to, że mię nie rozumie, że języka swego mi zaprzecza, że moralnie odpycha mię - to, że nikt w niej nie chce albo nie może pojąć, iż samochcąc idzie do upadku... to, że nikt w niej nie chce albo nie może pojąć, że światłość w ciemnościach świeci, a ciemności jej nie ogarnęły - to, że chce książek nie prawd, śmierci nie życia - że chce nowin i jasnych przypowieści - choć nikt się nic jeszcze nie nauczył z książek jasnych - owszem, wszystko od ciemnego się pojmowania rozpoczyna, bowiem światłość w ciemnościach świeci. $[\ldots]$

Jako Kościót - do którego przez lat parę wstąpić myśl miałem i pracowałem wewnątrz nad tym - to: że gdybym dziś zakonnikiem stał się - jutro herezję zrobiłbym - nie mogąc wchodzić do Kościoła kontemplacji, bo w tym trwam i jestem, ale jako czynnik i pracownik. A Kościół, który na Anglię nie przez boleść irlandzką - a na Rosję nie przez boleść polską działa - nie obowiązuje mię w swej akcji. I o ile jest $w$ tej akcji, zginie za niewiele już czasów, bo apostolstwo nie jest dyplomacją i kuglarstwem, i kabalistyką, ale proroctwem szczerym.

Jako familia - dwa moralne upiory braci dwóch: jeden ofiara szlachetności swojej - drugi nieszlachetności obcych.

Jako społeczeństwo - to, że próbowałem i MYŚL OGÓLNĄ MIAŁEM W TYM próbując - nie książką i literą, i dedukcjami Chrystianizmu, ale całym sobą: sumieniem, sercem, żołądkiem, nerwami, frakiem - czyli jest podobieństwo zespołecznić nieszczęścia-ekscentryczność z ześrodkowaniem pomyślności - i widzę, że niepodobieństwo [DWsz 10, 271-272].

Zgodnie z dzisiejszymi konwencjami semantycznymi powtarzane po wielekroć jako należałoby tu rozumieć jako element wprowadzający informację o jakimś aspekcie życia czy działania samego autora wypowiedzi. Słownikjęzyka polskiego pod redakcją Witolda Doroszewskiego definuje tego typu użycia 
jak w następujący sposób: „wyraz wiążący z wyrazem nadrzędnym rzeczowniki (rzadziej występujące w ich funkcji przymiotniki lub imiesłowy) uwydatniające funkcję, szczególny charakter czego, zajęcie, stanowisko, rolę pełnioną w stosunku do czego itp." ${ }^{12}$. Jeszcze bardziej szczegółową eksplikację proponuje Wielki słownik języka polskiego, w którym wyróżniono trzy znaczenia jako: 1. 'wskazuje się na taką cechę, która pozwala zrozumieć rolę danego obiektu w tym, o czym mowa' (tzw. wykładnik funkcji, np.: widziany jako pierwszy); 2. 'nadawca wskazuje na taką cechę obiektu, która pozwala zrozumieć to, o czym mowa' (tzw. wykładnik uzasadnienia, np.: jako Polaka interesuje mnie przyszłość); 3. 'to, o czym mowa, dzieje się w czasie, kiedy dana osoba była tym, o kim mowa' (tzw. wykładnik lokalizacji w czasie, np.: jako dziecko czuła się samotna) ${ }^{13}$. Zgodnie z tą propozycją da się interpretować tylko jedno połączenie obecne w obu zacytowanych fragmentach: „Jako członek Ojczyzny”. W pozostałych użyciach nie wydaje się ona trafna, ponieważ zastosowane w tym katalogu rzeczowniki czy grupy nominalne nie nazywają funkcji, atrybutów, etapów i aspektów życia czy działania Norwida, lecz raczej składające się na to życie zjawiska duchowe, intelektualne i społeczne, które mogą stanowić zadany przez adresata przedmiot rozważań i wobec których autor wypowiedzi jakoś się określa. Anaforycznemu jako należałoby więc przypisać parafrazę 'jeśli idzie o..., co do....'

Taką samą funkcję pełnią również niektór użycia jak:

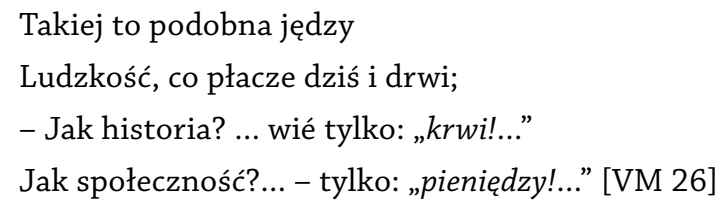

Powyższy cytat z Larwy można odczytywać na różne sposoby, między innymi takie, w których zdania rozpoczynające się od jak uznaje się za zdania czasowe ('kiedy [dzieje się/rozgrywa się] historia', 'kiedy [powstaje/formuje się] społeczność) lub porównawcze ('tak jak [robi to] historia', 'tak jak [robi to] społeczność]). Żadna z tych propozycji nie przekonuje jednak całkowicie; co więcej, każda z nich zakłada istnienie w tekście jakiejś elipsy. Dostrzeżenie w jak wykładnika sensu 'jeśli idzie o..., co do...' pozwala zrozumieć omawiany fragment bez przyjmowania dodatkowych założeń i pokazuje, że chodzi w nim o postawę ludzkości wobec dwóch przywołanych tu zjawisk czy jeszcze inaczej - o wartości, do jakich ludzkość dąży w konfrontacji z historią i społecznością.

N

Operacji uwydatniania tematu służy w tekstach Norwida także grafia (przede wszystkim znaki przestankowe i podkreślenia), która stanowi swoisty ekwiwalent suprasegmentalnych wykładników STR w tekście pisanym ${ }^{14}$.

\footnotetext{
${ }^{12}$ Stownik języka polskiego, red. W. Doroszewski, http://doroszewski.pwn.pl/haslo/jako/, dostęp 19.08.2021.

${ }^{13}$ Zob. Wielki słownik języka polskiego, red. P. Żmigrodzki, https://wsjp.pl/index.php?id_hasla=30252\&id_ znaczenia $=5166912 \& \mathrm{l}=12 \&$ ind=0, dostęp 20.08.2021.

${ }^{14} \mathrm{Na}$ temat funkcji Norwidowskiej grafii zob. Anna Kozłowska, „Grafia Cypriana Norwida jako sygnał struktury tematyczno-rematycznej wypowiedzenia”, w: Język pisarzy: środki artystycznego wyrazu, red. T. Korpysz, A. Kozłowska (Warszawa: Wydawnictwo Uniwersytetu Kardynała Stefana Wyszyńskiego, 2019), 101-125.
} 
W przywoływanych już ustaleniach Jolanty Chojak sygnałem topikalizacji okazały się wewnątrzzdaniowe pytajniki:

Ja? nazywam się czynność - prawda?... marność! [VM 20]

Im zdaje się że dziewięć panien kałamarze

Noszą mu [mowa o poecie - A.K.], a warkocze każdej jak kometa;

A wzrok? jak nieba lazur, lub noc południowa -

Szaty? jak obłok, poszept? jak mgła porankowa [VM 134]

Badaczka wykazała, że stosowany przez poetę znak nie wprowadza do wypowiedzenia standardowej intencji pytajnej, ale zamysł uwypuklenia jego tematu jest „wykładnikiem antykadencji oraz akcentu kontrastywnego. Konstytuuje specyficzny typ zdań z jawnie wyrażonym wyodrębnionym tematem, do których istoty należy «ukryty» kontrast, przeciwstawiający aktualny temat wypowiedzi wszelkim innym możliwym do pomyślenia tematom"15. $\mathrm{Na}$ przykład znaki zapytania pojawiające się w ciągu zaprzeczonych definicji poetyckich z Królestwa:

- Prawda? nie jest przeciwieństw-mikstura...

$[\ldots]$

Orzeł? nie jest pół-żółwiem, pół-gromem

Słońce? nie jest pół-dniem a pół-nocą,

Spokój? nie jest pół-trumną, pół-domem

Łzy? nie deszcz są, choć jak deszcz wilgocą [VM 55]

sygnalizują następujące znaczenie: 'mówię o prawdzie / orle / słońcu / spokoju / łzach, a nie o czymś innym, o czym można by pomyśleć'.

Niekiedy pytajniki są wspierane w omówionej wyżej roli przez podkreślenia, które u autora Vade-mecum także często wyrażają aktualne rozczłonkowanie wypowiedzi. Na przykład we fragmencie Wielkich-słów zaakcentowanie tematu, a tym samym - wyboru właśnie tych, a nie innych postaci ('mówię właśnie o Cyceronie / Pawle / Sokratesie, a nie o żadnym innym człowieku, o którym można by pomyśleć'), wydało się Norwidowi na tyle ważne, że uznał za zasadne uruchomienie obu wykładników topikalizacji jednocześnie:

Czy, zapytaliście czemu $\underline{\text { Cicero? }}$

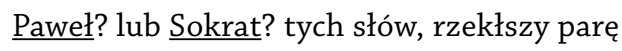

Żyją... do dzisiaj cię za piersi bierą,

A ty choćbyś im nierad, dawasz wiarę [VM 99].

${ }^{15}$ Chojak, 31-32. 
Niektóre Norwidowskie podkreślenia stanowią także samodzielny sygnał wyróżnienia tema$\mathrm{tu}^{16}$. Taką funkcję pełnią na przykład w poniższych przykładach:

Narcyz, w siebie wpatrzon przyjemnie:

„Zważ!” wyzywał „wszelki człowiecze:

Cóż? nad Grecję (bo cóż, nade mnie)".

- Echo jemu prosto odrzecze (VM 29);

Lapońscy, wzięli księdza w swe obroty [VM 96];

Parabola, jest obraz, pieśń jest duch obrazu [DWsz 4, 237].

Niekiedy Norwid podkreślał tylko jeden element wyrażenia tematycznego, akcentując tym samym jego złożoność i hierarchiczność. Tak można interpretować na przykład czerwone podkreślenie formy „pierwszą” we wstępie do Rzeczy o wolności słowa ${ }^{17}$ :

Pierwszą, słowa formą zdaje się być wewnętrzna pieśn i monolog którego ślady do dziś w pustelnictwie indyjskim spotykają się [DWsz 4, 213].

Funkcję wyróżniania tematów pełnią w tekstach Norwida także podwojone przecinki, okalające wybrany element wypowiedzi. Przykład takiego zabiegu spotykamy między innymi w inicjalnych wersach tytułowego utworu Vade-mecum:

Klaskaniem mając obrzękłe prawice

Znudzony pieśnią, lud, wołał o czyny [VM 12].

Marta Rogowska, autorka ważnego artykułu o interpunkcji Norwida, dostrzega w tym miejscu intonacyjne wyróżnienie słowa „lud” „przez krótkie zawieszenie głosu przed i po nim”, a za główny cel tego zabiegu uważa „zwrócenie uwagi czytelnika na dany fragment wypowiedzi” oraz

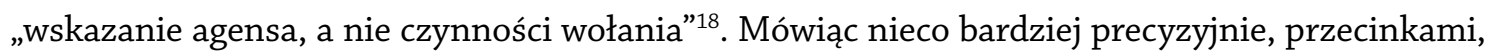
a zatem i pauzami oraz wymuszoną zmianą intonacji (antykadencją) wyodrębnił poeta główny człon części tematycznej ${ }^{19}$, sygnalizując intencję mówienia o ludzie, a nie o czymś innym. Obserwacja Rogowskiej dotycząca rysującego się tu kontrastu jest zatem trafna, choć kontrast ten nie zachodzi między agensem a czynnością, ale między aktualnym tematem a potencjalnymi innymi tematami wypowiedzi.

\footnotetext{
${ }^{16}$ Autorka rozprawy o Norwidowskich podkreśleniach, Barbara Subko, wspomina, że poeta wyróżniał podkreśleniami zdania tematyczne, czyli takie, które „wprowadzają nowy topik (temat) w obrębie akapitu czy większej części tekstu” (B. Subko, „O podkreśleniach Norwidowskich - czyli o podtekstach metatekstu”, Studia Norwidiana 9-10 [1991-1992]: 55), ale przywołane przykłady pokazują, że autorka miała chyba na myśli temat w sensie treściowym, bez odniesienia do problematyki aktualnego rozczłonkowania zdania.

${ }^{17}$ Być może warto byłoby przeanalizować w tej perspektywie formalne zróżnicowanie Norwidowskich podkreśleń, którego w tym szkicu ze względu na jego wstępny charakter nie uwzględniam. Podkreślenia stosowane przez poetę miewają przecież - jak zauważyła Barbara Subko - różny kolor, kształt, bywają jedno- lub wielokrotne. Poeta wprowadzał je również na rozmaitych etapach powstawania tekstu - czasem już podczas pisania, a niekiedy w trakcie ponownej lektury czy lektur (zob. Subko, 45).

${ }^{18}$ Marta Ewa Rogowska, „O intonacyjno-retorycznej roli Norwidowskiej interpunkcji”, Studia Norwidiana 30 (2012): 26-27.

${ }^{19}$ Przecinek między „lud” a „wołał” można również interpretować jako sygnał cezury tematycznej.
} 
Podobna sytuacja pojawia się w drugim wersie fragmentu Rzeczy o wolności słowa:

I to własny jej obraz - i ten ją zagładza:

Tak, Ludzkość, bez Boskości sama siebie zdradza [DWsz 4, 218] ${ }^{20}$.

W przecinkach zostało tu zapisane słowo „Ludzkość”, wyróżnione jeszcze dodatkowo podkreśleniem oraz wielką literą. Oba te sygnały dość wyraźnie świadczą o tym, że w zamierzeniu autora wyrażenie „bez Boskości”, któremu bez tych dodatkowych wskazówek można by przypisać dwojaką intepretację składniową („Ludzkość bez Boskości” - „bez Boskości sama siebie zdradza”), wchodzi w skład części rematycznej: Ludzkość (T) bez Boskości sama siebie zdradza (R). 'Jeśli idzie o Ludzkość, to bez Boskości sama siebie zdradza' - tak można by sparafrazować sens omówionego fragmentu.

Na zakończenie tej części warto raz jeszcze podkreślić, że poeta niejednokrotnie decydował się na jednoczesne zastosowanie dwóch graficznych wykładników topikalizacji. W jego tekstach najczęściej chyba łączone są ze sobą następujące znaki wskazujące na wyróżnienie tematu:

- pytajnik i podkreślenie:

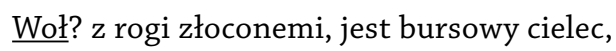

Żołądek? jest publiczność, doktryner? widelec [VM 137 $]^{21}$

- przecinki i podkreślenie:

(: nawet w arcydziełach starożytnych, moc, głównym jest wdziękiem:) [DWsz 4, 214].

V

Zabiegi zmierzające do uwydatnienia tematu pokazują, że w Norwidowej praktyce konstruowania wypowiedzeń fundamentalną rolę odgrywa ukryty kontrast. Właśnie kontrast leży bowiem u podstaw topikalizacji, której poeta używał przede wszystkim w dwóch funkcjach: 1 . wskazywania, że w wypowiedzi mowa o X, a nie o jakimkolwiek innym możliwym do pomyślenia temacie, oraz 2. (rzadziej) doprecyzowywania, że tematem jest X, a nie żaden inny obiekt, który można by wybrać z jakiejś sygnalizowanej wcześniej klasy.

Obserwując topikalizację (oraz inne zjawiska związane z STR), można również dostrzec, że komunikacja Norwida z czytelnikiem rozgrywa się jednocześnie na kilku poziomach: poeta dokonuje aktu predykacji, odnosząc się do danego obiektu, narzuca swojej wypowiedzi określoną strukturę wiedzy, czyli wyodrębnia w niej temat i remat, a także dostarcza czytelnikowi silnych sygnałów uwypuklających tę stukturę. W przypadku topikalizacji sygnałom tym można przypisać następującą intencję: 'mówię o X, a nie o Y, Z... itp.'.

\footnotetext{
${ }^{20} \mathrm{~W}$ autografie cały wers jest dodatkowo podkreślony pomarańczową kredką.

${ }^{21}$ Przykład ten pokazuje również brak konsekwencji Norwida w stosowaniu znaków graficznych - z dwóch elementów o funkcji tematu obecnych w tym ciągu pierwszy („żołądek”) został wyróżniony podkreśleniem z pytajnikiem (i tym samym ilustruje on omawiane połączenie znaków), drugi („doktryner”) - tylko pytajnikiem.
} 
Omawiana operacja wpisuje się w charakterystyczną dla Norwida strategię mówienia, którą można by nazwać strategią nadmiaru. Wydaje się, że autor Vade-mecum zawsze chce powiedzieć więcej, niż pozwalają mu standardowe mechanizmy języka; dąży do tego, aby pokazać możliwie wiele opcji i ukazać zgłębiany problem z różnych perspektyw. Temu służy między innymi właśnie wyróżnianie tematu, który w naturalnym porządku usuwa się na dalszy plan, podczas gdy w pismach Norwida nawet w wypowiedzeniach o nienacechowanej diatezie i neutralnym szyku pozostaje często wyesponowany graficznie. Skutkuje to zacieraniem wyrazistości podziału na część tematyczną i rematyczną, swoistą migotliwością w ich wyznaczaniu, sugerującą, że zarówno główny temat, jak i remat są równie ważne w hierarchii wypowiedzenia.

Jak widać, uwzględnianie kwestii topikalizacji i szerzej - mechanizmów z poziomu STR w analizie tekstów Norwida rzuca nowe światło na specyfikę idiolektu i zabiegów tekstotwórczych Norwida, ponieważ niektóre z jego charakterystycznych „chwytów” (takie jak inwersje, wybrane parentezy, anakoluty składniowe czy grafia) zasadzają się właśnie na wykorzystaniu mechanizmów z poziomu STR. Pozwala ono również rozwikłać wiele problemów ze zrozumieniem tekstu, nierozstrzygalnych na poziomie relacji czysto składniowych, i stwarza szansę na ewentualne przełożenie uzyskanych wniosków na odpowiednią interpretację głosową. Last but not least - jest ono wreszcie istotne ze względu na poprawność metodologiczną, ponieważ w lekturze - nie tylko tekstów Norwida - mamy przecież do czynienia nie z "abstrakcyjnie bladymi” (por. PWsz 6, 232) schematami składniowymi, tylko ze zdaniami użytymi, zrealizowanymi i zaktualizowanymi, czyli z wypowiedzeniami ${ }^{22}$, których niezbywalnym, wyróżniającym komponentem jest właśnie rozczłonkowanie na to, o czym się mówi, i na to, co jest powiedziane.

\footnotetext{
${ }^{22} \mathrm{Na}$ temat odróżniania zdań od wypowiedzeń zob. J. Wajszczuk, O metatekście, Warszawa 2005; M. Żabowska, Makroskładnia - wypowiedzeniowe struktury syntaktyczne, „Linguistica Copernicana” 2017, nr 14, s. 71-87.
}

\section{Bibliografia}

Biblioteka Cyfrowa Muzeum Narodowego w Krakowie, http://cyfrowe.mnk.pl/dlibra/doc metadata?id=19716\&from=pubindex\&dirids= 1\&lp=179. Dostęp 4.11.2020.

Bogusławski, Andrzej. Problems of the ThematicRhematic Structure of Sentences. Warszawa: Państwowe Wydawnictwo Naukowe, 1977.

- - -. A Study in the Linguistics - Philosophy Interface. Warszawa: BEL Studio, 2007.

Chojak, Jolanta. „Echa nie zadanych pytań czy wyróżnione tematy (o pewnych użyciach Norwidowskiego pytajnika)". W: Studia nad jezzykiem Cypriana Norwida, red. J. Chojak, J.
Puzynina, 13-36. Warszawa: Wydawnictwo Uniwersytetu Warszawskiego, 1990.

Chojak, Jolanta, Zofia Zaron. „Wyznaczniki tematu wypowiedzi”, Polonica XXIV-XXV (2005): 21-32.

Ciołek, Anna. „Imiesłowowe równoważniki zdań w listach C.K. Norwida”. Poradnik Językowy 7 (2015): 23-31.

Grochowski, Maciej. „Składnia wyrażeń polipredykatywnych". W: Gramatyka wspótczesnego języka polskiego. Składnia, red. Z. Topolińska. Warszawa: Wydawnictwo PWN, 1984. 
- - -. „Metatekstowa interpretacja parentezy”. W: Tekst i zdanie. Zbiór studiów, red. T. Dobrzyńska, E. Janus, 247-258. Wrocław: Ossolineum, 1983.

Huszcza, Romuald. „Tematyczno-rematyczna struktura zdania w języku polskim". Polonica VI (1980): 57-81.

- - -. „Tematyczno-rematyczna struktura zdania w językach różnych typów. (Normalny podział tematyczno-rematyczny)". W: Tekst w kontekście, red. T. Dobrzyńska, 55-95. Wrocław: Ossolineum, 1990.

Karolak, Stanisław. „Aktualne rozczłonkowanie zdania”. W: Encyklopedia językoznawstwa ogólnego, red. K. Polański, 30-33. Wrocław: Ossolineum, 1995.

Kozłowska, Anna. „Grafia Cypriana Norwida jako sygnał struktury tematycznorematycznej wypowiedzenia". W: Język pisarzy: środki artystycznego wyrazu, red. T. Korpysz, A. Kozłowska, 101-125. Warszawa: Wydawnictwo Uniwersytetu Kardynała Stefana Wyszyńskiego, 2019.

- - -. „Kilka uwag o archaicznych elementach składniowych w tekstach Cypriana Norwida”. Studia Norwidiana 29 (2011): 99-117.

Norwid, Cyprian. Dzieła wszystkie, red. S. Sawicki: t. 3. Poematy cz. I, oprac. S. Sawicki, A. Cedro (Lublin: Towarzystwo Naukowe KUL, 2009); t. 4. Poematy cz. II, oprac. S. Sawicki, P. Chlebowski (Lublin: Towarzystwo Naukowe KUL, 2011); t. 5. Dramaty cz. I, oprac. J. Maślanka (Lublin: Towarzystwo Naukowe KUL, 2015); t. 6. Dramaty cz. II, oprac. J. Maślanka (Lublin: Towarzystwo Naukowe KUL, 2013); t. 7. Proza cz. I, oprac. R. Skręt (Lublin: Towarzystwo Naukowe KUL, 2007); t. 10. Listy cz. I, 1839-1854, oprac. J. Rudnicka (Lublin: Towarzystwo Naukowe KUL, 2008); t. 11. Listy cz. II, oprac. J. Rudnicka (Lublin: Towarzystwo Naukowe KUL, 2016); t. 12. Listy cz. III, oprac. J. Rudnicka, uzup. E. Lijewska (Lublin: Towarzystwo Naukowe KUL, 2019).

- - -. Pisma wszystkie. Zebrał, tekst ustalił, wstępem i uwagami krytycznymi opatrzył J.W. Gomulicki, t. 1-11. Warszawa: Państwowy Instytut Wydawniczy, 1971-1976.
- - -. Vade-mecum, oprac. J. Fert. Lublin: Towarzystwo Naukowe KUL, 2004.

- - -. „Vade-mecum”. Transliteracja autografu, oprac. i wstępem opatrzył M. Grabowski. Łódź: Wydawnictwo Uniwersytetu Łódzkiego, 2018.

Polona. www.polona.pl.

Pisarkowa, Krystyna. Historia składni języka polskiego. Wrocław: Ossolineum 1984.

Puzynina, Jadwiga. „Z problemów składni w tekstach poetyckich Norwida (na materiale Vade-mecum)", 95-114. W tejże: Słowo Norwida, Wrocław: Ossolineum, 1990.

Rogowska, Marta Ewa. „O intonacyjnoretorycznej roli Norwidowskiej interpunkcji". Studia Norwidiana 30 (2012): 23-38.

Słoboda, Agnieszka. „Imiesłowy u Norwida”. Poznańskie Studia Polonistyczne. Seria Językoznawcza 8 (2001): 139-150.

Słownik języka polskiego, red. W. Doroszewski, wersja elektroniczna: http://doroszewski.pwn. pl. Dostęp 19.08.2021.

Subko, Barbara. „O podkreśleniach Norwidowskich - czyli o podtekstach metatekstu". Studia Norwidiana 9-10 (19911992): 45-64.

Topolińska, Zuzanna. „Informacja zgramatykalizowana (kryteria selekcji)”. Biuletyn PTJ LXVIII (2013): 69-85.

Wajszczuk, Jadwiga. O metatekście. Warszawa: Katedra Lingwistyki Formalnej UW, 2005.

Wielki słownik języka polskiego, red. P. Żmigrodzki, https://wsjp.pl. Dostęp 20.08.2021.

Żabowska, Magdalena. „Makroskładnia wypowiedzeniowe struktury syntaktyczne”. Linguistica Copernicana 14 (2017): 71-87. 


\title{
SŁOWA KLUCZOWE:
}

\section{T E M A T}

\section{Cyprian Norwid}

\section{D I O L E K T}

\begin{abstract}
AbSTRAKT:
Topikalizacja, rozumiana jako uwydatnienie tematu wypowiedzenia, ma w twórczości Cypriana Norwida rozmaite wykładniki syntaktyczne, leksykalne i graficzne - te ostatnie, specyficzne dla wypowiedzi autora Vade-mecum, stanowią swoisty ekwiwalent suprasegmentalnych wykładników struktury tematyczno-rematycznej w tekście pisanym. Omawiana operacja wprowadza do wypowiedzi ukryty kontrast, wskazując, że mowa w niej właśnie o X, a nie o jakimkolwiek innym możliwym do pomyślenia temacie ani też nie o obiekcie, który można by wybrać z jakiejś sygnalizowanej wcześniej klasy. Towarzyszy jej następująca intencja: 'mówię o X, a nie o Y, Z... itp.'. Zaciera ona wyrazistość podziału na część tematyczną i rematyczną i tym samym wpisuje się w charakterystyczną dla Norwida strategię mówienia, w której zarówno główny temat, jak i remat wypowiedzenia wydają się równie ważne.
\end{abstract}




\title{
STRUKTURA TEMATYCZNO-REMATYCZNA
}

\author{
topikalizacja
}

\section{NOTA O AUTORCE:}

Anna Kozłowska (1973) - dr hab., profesor Uniwersytetu Kardynała Stefana Wyszyńskiego w Warszawie. Dyrektor Instytutu Językoznawstwa, kierownik Katedry Badań nad Językiem Autorów. W latach 1996-2003 członek zespołu Pracowni Słownika Języka Cypriana Norwida Uniwersytetu Warszawskiego. Główne zainteresowania: język pisarzy, zwłaszcza Cypriana Norwida i Karola Wojtyły, metodologia językoznawstwa, stylistyka i składnia. Autorka licznych prac naukowych z zakresu językoznawstwa i norwidologii, w tym monografii Chrześcijaństwo w pismach Cypriana Norwida (2000; jako Anna Kadyjewska; współautorzy: Tomaszl Korpysz, Jadwiga Puzynina) i Od psalmów stowiańskich do rzymskich medytacji. O stylu artystycznym Karola Wojtyły (2013), redaktor kilku tomów zbiorowych, współorganizator cyklu konferencji poświęconych językowi pisarzy. 